\title{
Understory vegetation plays the key role in sustaining soil microbial biomass and extracellular enzyme activities
}

\author{
Yang Yang ${ }^{1,2,3}$, Xinyu Zhang ${ }^{2,3}$, Chuang Zhang ${ }^{4}$, Huimin Wang ${ }^{2,3}$, Xiaoli Fu ${ }^{2,3}$, Fusheng Chen ${ }^{5}$, Songze Wan ${ }^{5}$, \\ Xiaomin Sun ${ }^{2,3}$, Xuefa Wen ${ }^{2,3}$, and Jifu Wang ${ }^{1}$ \\ ${ }^{1}$ College of Geographic Science, Harbin Normal University, Harbin, 150025, China \\ ${ }^{2}$ Key Laboratory of Ecosystem Network Observation and Modeling, Institute of Geographic Sciences and Natural Resources \\ Research, Chinese Academy of Sciences, Beijing, 100101, China \\ ${ }^{3}$ College of Resources and Environment, University of Chinese Academy of Sciences, Beijing, 100049, China \\ ${ }^{4}$ Key Laboratory of Agricultural Water Resources, Center for Agricultural Resources Research, Institute of Genetic and \\ Developmental Biology, The Chinese Academy of Sciences, 286 Huaizhong Road, Shijiazhuang, 050021, Hebei, China \\ ${ }^{5}$ College of Forestry, Jiangxi Agricultural University, Nanchang, 330045, China
}

Correspondence: Xinyu Zhang (zhangxy@igsnrr.ac.cn) and Jifu Wang (13946004918@163.com)

Received: 19 December 2017 - Discussion started: 16 January 2018

Revised: 10 June 2018 - Accepted: 10 July 2018 - Published: 24 July 2018

\begin{abstract}
While we know that understory vegetation affects the soil microbial biomass and extracellular enzyme activities in subtropical Chinese fir (Cunninghamia lanceolata) forests, we are less certain about the degree of its influence. We determined the degree to which the soil abiotic and biotic properties, such as PLFAs and extracellular enzyme activities, were controlled by understory vegetation. We established a paired treatment in a subtropical Chinese fir plantation, which comprised one plot from which the understory vegetation and litter were removed (None) and another from which the litter was removed but the understory vegetation was left intact (Understory). We evaluated how the understory vegetation influenced the soil abiotic properties, the bacterial, fungal, and actinobacterial PLFAs, and the activities of five hydrolases and two oxidative enzymes. The dissolved organic carbon (DOC), particulate organic carbon, soil organic carbon, ammonia nitrogen $\left(\mathrm{NH}_{4}^{+}-\mathrm{N}\right)$, and total nitrogen contents and soil moisture were $18 \%, 25 \%, 12 \%$, $34 \%, 8 \%$, and $4 \%$ lower in the None treatments than in the Understory treatments, respectively $(P<0.05)$. Soil bacterial, fungal, and total PLFAs, and the potential activities of $\beta$ 1,4-glucosidase $(\beta \mathrm{G}), \beta$-1,4-N-acetylglucosaminidase, phenol oxidase, and peroxidase, were as much as $24 \%$ lower in None treatments than in Understory treatments $(P<0.05)$. The specific activities of $\mathrm{C}$-acquiring enzymes were as much as $41 \%$ higher $(P<0.05)$, and the ratio of $\mathrm{C}$ - to $\mathrm{N}$-acquiring
\end{abstract}

enzymes was also higher in the None treatments than in the Understory treatments. This suggests that in the absence of understory vegetation microbes invested more in $\mathrm{C}$ acquisition than $\mathrm{N}$ acquisition because the carbon (C) inputs were less labile. The negative relationship between DOC and AP shows that DOC is consumed when $\mathrm{P}$-acquiring enzymes are produced. The positive correlation between $\mathrm{NH}_{4}^{+}-\mathrm{N}$ and $\beta \mathrm{G}$ suggested the increased availability of $\mathrm{N}$ promoted the decomposition of $\mathrm{C}$. More extracellular enzymes that degrade soil organic matter are produced when there is understory vegetation, which leads to losses of soil $\mathrm{C}$. On the other hand, the soil $\mathrm{C}$ sink is maintained by increased inputs of $\mathrm{C}$. We can therefore conclude that understory vegetation contributes to $\mathrm{C}$ sequestration in Chinese fir forests and suggest that understory should be maintained to sustain soil quality in subtropical Chinese fir plantations.

\section{Introduction}

The interactions that occur between above-ground vegetation functional groups and soil microbial communities are thought to be important drivers of carbon (C) and nutrient cycling in terrestrial ecosystems (Murugan et al., 2014). When understory vegetation is removed from forest ecosystems, soil processes are influenced, such that above-ground plant 
diversity and biomass decrease (Lamb et al., 2011; Fu et al., 2015) and the characteristics of the below-ground rhizodeposits change ( $\mathrm{Li}$ et al., 2013). The understory vegetation absorbs water and nutrients from soil (Wang et al., 2014), and also releases carbohydrates back to the soil as discarded root cap and border cells, mucilage and exudates from roots (McNear Jr., 2013), and cellulose, hemicelluloses, and lignin from leaf litter (Loeppmann et al., 2016a, b). The net effect of understory vegetation on soil nutrients is determined by the balance between its nutrient demand and capacity to release carbohydrates to soil via the decomposition of understoryderived litter and rhizodeposits.

Soil extracellular enzymes produced by microorganisms or plant roots catalyze the cycling of soil $\mathrm{C}$, nitrogen $(\mathrm{N})$, and phosphorus (P) (Burns et al., 2013; Nannipieri et al., 2018). Because they respond rapidly to soil environmental changes, soil enzyme activities are often used as indicators of soil quality (Trasar-Cepeda et al., 2008; Burns et al., 2013). Individual enzyme activities can reflect the substrate availability, the nutrient requirements of microorganisms and plants, and the strategies used by microbes and plants to maintain the nutrient balance when the soil environment changes (Burns et al., 2013; Nannipieri et al., 2018). Because it is difficult to know whether changes in the enzymatic activities reflect changes in the soil microbial biomass or differences in the actual activities (Trasar-Cepeda et al., 2008), we need to study the specific enzyme activities, i.e., the activity normalized to the total PLFA contents (Zhang et al., 2015, 2017). The enzyme ratio is used to examine the relative allocation of energy versus nutrient acquisition, since it intersects the metabolic theory of microbial ecology and the theory of ecological stoichiometry (Stone et al., 2014; Loeppmann et al., 2016a; Xu et al., 2017). By studying how the enzyme activities and ratios change when the understory vegetation is removed, we hope to improve our understanding of how the storage of $\mathrm{C}$ in soil is influenced by the understory vegetation, and how microbial nutrient acquisition is affected by microbial biomass and soil nutrients.

Studies have shown that understory vegetation-induced changes in soil properties are closely related to climate, soil type, plant species, and time (Li et al., 2013; Nilsson and Wardle, 2005; Zhang et al., 2014). There is however no consensus on how understory vegetation impacts the physical, chemical, and biological properties of forest soils. For example, some studies have reported decreases in the litter decomposition rate, soil organic matter (SOM) content, and soil respiration rate (Wang et al., 2011, 2014; Liu et al., 2012), while others have reported little change in the soil properties after understory vegetation was removed (Xiong et al., 2008; Zhao et al., 2011). Wu et al. (2011) and Zhao et al. (2013) found that the fungal biomass and the fungi to bacteria ratio decreased, but Murugan et al. (2014) found that the bacterial and saprophytic fungal biomass increased, and ectomycorrhizal fungi and arbuscular mycorrhizal fungi decreased after understory vegetation was removed from eucalyptus plan- tations. In an alpine shrubland, the soil arbuscular mycorrhizal fungal biomass decreased 5 months after plant functional groups were removed, but this effect disappeared after 17 months (Urcelay et al., 2009). The effects of understory vegetation on soil microbial biomass vary by ecosystem type. Huang et al. (2014) reported that soil enzyme activities decreased in a subtropical alpine coniferous forest, while Lin et al. (2012) found that they did not change in a Pinus sylvestris var. mongolica plantation when understory vegetation was removed. The current information about the responses of soil enzyme activities to understory vegetation removal is therefore inconsistent.

Yu et al. (2014) reported that the average net ecosystem productivity of Chinese subtropical forests (362 \pm $39 \mathrm{~g} \mathrm{C} \mathrm{m}^{-2} \mathrm{yr}^{-1}$ ) was approximately $82.6 \%$ and $64.9 \%$ higher than that of tropical and temperate forests. To maintain soil fertility, it is important that $\mathrm{C}$ sinks and tree growths are sustained in these forests. A valuable economic resource, Chinese fir (Cunninghamia lanceolata) plantations are widespread throughout southern China. They cover an area of $9.11 \times 10^{6}$ ha, and account for approximately $18 \%$ of the total plantation area in China (Huang et al., 2013). Understory vegetation and litter are commonly removed from the forest floor in southern China and elsewhere to facilitate seed germination; ensure survival of seedlings; avoid the intense competition between understory vegetation and trees for water, nutrients, and light; and for fuel for rural inhabitants (Xiong et al., 2008; Wu et al., 2011; Liu et al., 2012).

Therefore, we established a long-term field experiment to assess how the soil abiotic properties, PLFAs, and enzyme activities in a Chinese fir plantation changed when the understory vegetation was removed. We hypothesized that rhizodeposition, and therefore microbial biomass and activity, would decrease when the understory vegetation was removed.

\section{Material and methods}

\subsection{Experimental treatments}

Our study site was in the Shixi forest plantation in Taihe County, Jiangxi Province, China $\left(115^{\circ} 03^{\prime} 29.9^{\prime \prime} \mathrm{E}\right.$, $\left.26^{\circ} 44^{\prime} 29.1^{\prime \prime} \mathrm{N}\right)$. The area has a subtropical monsoon climate with a mean annual temperature of $18.8^{\circ} \mathrm{C}$ and a mean annual precipitation of $1340 \mathrm{~mm}$. According to the USDANRCS soil taxonomy (Soil Survey Staff, 1999), the soil in this area is dominated by Udults, which forms from red sandstone and sandy conglomerate and has moist and dry Munsell values of 7.5 YR 5/6 and 7.5 YR 6/6, respectively.

The study site is a second-generation Chinese fir plantation that was planted in 1998. The average tree height and diameter at breast height (measured at $1.3 \mathrm{~m}$ above ground level) were about $18 \mathrm{~m}$ and $17 \mathrm{~cm}$, respectively. The understory vegetation, including shrubs and herbs, is dominated by Old World forked fern (Dicranopteris dichotoma Berth), gambir 


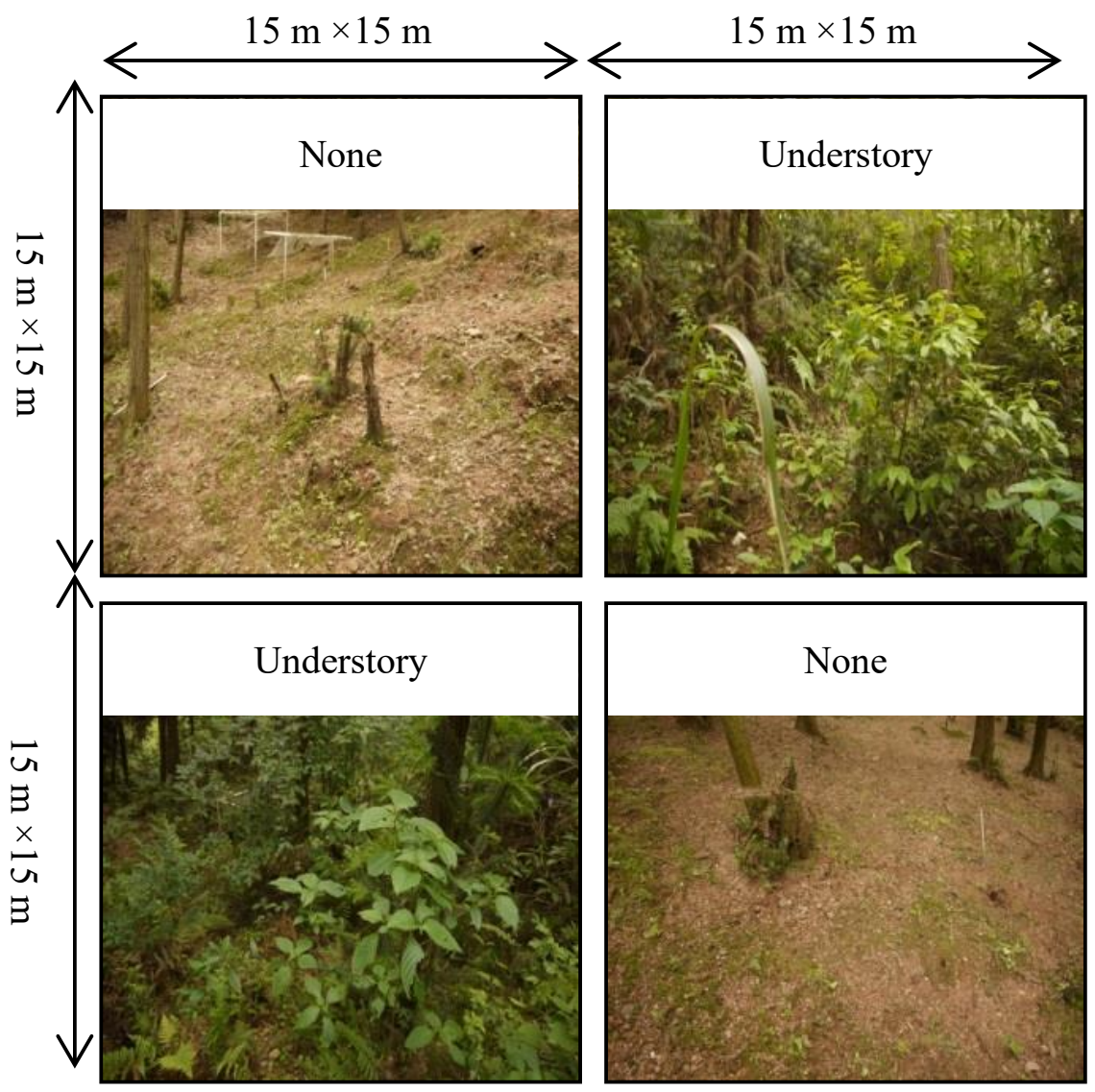

Figure 1. Paired-plot design treatments with understory vegetation and litter removal (None), and understory vegetation intact and litter removal (Understory). The same abbreviations are used below.

(Uncaria), oriental blueberry (Vaccinium bracteatum), nutgall tree (Rhus chinensis), Chinese witch hazel (Loropetalum chinense), short shank robe oak (Quercus glandulifera BI.), root of mayflower glorybower (Clerodendron cyrtophyllum Turcz), and azalea (Rhododendron).

Three plots, measuring $30 \times 30 \mathrm{~m}$ and separated by a buffer of a least $10 \mathrm{~m}$ to avoid any between-plot influence, were established in the plantation in January 2013. One paired treatment with three replicates was established within each of the three plots. Each plot was divided into four subplots $(15 \times 15 \mathrm{~m}$ each $)$ and contained two treatments, namely None, from which both the understory vegetation and litter were removed, and Understory, from which the litter was removed but the understory vegetation was left. The two subplots in a plot with the same treatment were distributed across each plot to avoid the effects of slope (Fig. 1) and their results were averaged. The litter and understory were managed monthly. The amount of litter and understory vegetation at the study site amounted to about 1020 and $6236 \mathrm{~kg} \mathrm{ha}^{-1} \mathrm{yr}^{-1}$, respectively, under natural conditions.

\subsection{Soil sampling and analysis}

Bulk soil samples were collected in the wet (April and November) and dry (July) seasons in 2015. Five soil cores with an inner diameter of $5 \mathrm{~cm}$ were collected randomly from between the surface and a depth of $10 \mathrm{~cm}$ from each subplot and then mixed as one composite sample. All fresh soil samples were sieved to $2 \mathrm{~mm}$ and stored at $4{ }^{\circ} \mathrm{C}$ until analysis.

Soil physical and chemical properties were determined as outlined by Bao (2008). Soil temperature (ST) was determined at a depth of $10 \mathrm{~cm}$ with a soil thermometer (TP101) during sampling. The soil moisture content (SMC) was measured by drying aliquots of soil at $105^{\circ} \mathrm{C}$ to constant weight. Soil $\mathrm{pH}$ was measured at a soil-to-water ratio of $1: 2.5$ by a $\mathrm{pH}$ digital meter. The contents of nitrate $\mathrm{N}\left(\mathrm{NO}_{3}^{-}-\mathrm{N}\right)$ and ammonia $\mathrm{N}\left(\mathrm{NH}_{4}^{+}-\mathrm{N}\right)$ were measured with a continuous flow analyser (Bran Luebbe, AA3) after extraction with a $2 \mathrm{M} \mathrm{KCl}$ solution (soil : solution ratio of $1: 10$ ). Dissolved organic carbon (DOC) contents were measured with a TOC analyser (Elementar, Liquid $I I$ ) after extraction with ultra-pure water (soil : solution ratio of $1: 5$ ) (Jones and Willett, 2006). Particulate organic carbon (POC) was determined as outlined by 
Garten et al. (1999). The contents of soil organic C (SOC) and total nitrogen (TN) were measured with an elemental analyser (Vario Max CN).

Soil phospholipid fatty acids (PLFAs) were extracted following the procedure outlined by Bossio and Scow (1998), and were determined with a gas chromatograph (Agilent $6890 \mathrm{~N})$. Soil total PLFAs were represented by various PLFA biomarkers; gram positive bacteria $\left(\mathrm{G}^{+}\right)$were represented by i14:0, i15:0, a15:0, i16:0, i17:0, and a17:0, and gram negative bacteria $\left(\mathrm{G}^{-}\right)$were represented by $16: 1 \omega 7 \mathrm{c}$, cy17:0, 16:1 $\omega 9 \mathrm{c}$, and cy19:0. The total bacterial PLFAs were represented by biomarkers of $\mathrm{G}^{+}$and $\mathrm{G}^{-}$. The total fungi PLFAs were represented by arbuscular mycorrhizal fungi (AMF) biomarkers 16:1 155 , as well as $18: 1 \omega 9 \mathrm{c}, 18: 2 \omega 6 \mathrm{c}$, and $18: 3 \omega 6 \mathrm{c}$, and the actinobacterial PLFAs were represented by $10 \mathrm{Me} 16: 0,10 \mathrm{Me} 17: 0$, and 10Me18 : 0 (Bradley et al., 2007; Denef et al., 2009).

Soil enzyme activities were measured following the methods of Saiya-Cork et al. (2002). The specific substrates and functions of the enzymes assayed are listed in Table A1. Five hydrolase activities, i.e., $\alpha$-1,4-glucosidase $(\alpha \mathrm{G}), \beta-1,4$ glucosidase $(\beta \mathrm{G}), \beta-1,4-\mathrm{N}$-acetylglucosaminidase (NAG), $\beta$-1,4-xylosidase $(\beta \mathrm{X})$ and acid phosphatase (AP) were assayed using fluorogenically labeled substrates. Briefly, a soil suspension was prepared by adding $1 \mathrm{~g}$ of fresh soil to $125 \mathrm{~mL}$ of $50 \mathrm{mM}$ acetate buffer. We added $200 \mu \mathrm{L}$ of the soil suspension and $50 \mu \mathrm{L}$ of the substrate solution $(200 \mu \mathrm{M})$ to 96 microplates, making a total of eight analytical replicates. Methylumbelliferone (MUB) was used to calibrate the hydrolase activities. The microplates were incubated in the dark at $20^{\circ} \mathrm{C}$ for up to $4 \mathrm{~h}$. After incubation, $10 \mu \mathrm{L}$ of $1 \mathrm{M} \mathrm{NaOH}$ was added to each well to terminate the enzymatic reaction. When the reactions had ended, the fluorescence was measured using a microplate fluorometer (SynergyH4, BioTek) with excitation and emission filters of 365 and $450 \mathrm{~nm}$, respectively. We calculated the specific enzyme activities by dividing the individual potential hydrolase activities by the total PLFA contents (Zhang et al., 2015, 2017). The total Cacquiring enzyme activity $\left(\mathrm{C}_{\mathrm{enz}}\right)$ was operationally defined as the sum of the $\alpha \mathrm{G}, \beta \mathrm{G}$, and $\beta \mathrm{X}$ activities (Stone et al., 2014) (Table A2).

The soil oxidase activities, i.e., polyphenol oxidase (PPO) and peroxidase (PER) were assayed spectrophotometrically. We added $600 \mu \mathrm{L}$ of the soil suspension and $150 \mu \mathrm{L}$ of the substrate solution to deep-well plates. We also added $30 \mu \mathrm{L}$ of $0.3 \% \mathrm{H}_{2} \mathrm{O}_{2}$ solution before determining PER. After incubation in the dark at $20^{\circ} \mathrm{C}$ for up to $5 \mathrm{~h}$, the deep-well plates were centrifuged for $3 \mathrm{~min}$ at $3000 \mathrm{rh}^{-1}$. We then transferred $250 \mu \mathrm{L}$ of the supernatant to the microplates and measured the absorbance at $450 \mathrm{~nm}$ with a microplate fluorometer (SynergyH4, BioTek) (DeForest, 2009).

\subsection{Statistical analysis}

Data are presented as the means \pm standard errors. By applying the one-sample Kolmogorov-Smirnov test within SPSS 17.0, we found that the data satisfied the normal distribution criteria. We assessed the differences between the soil abiotic properties, PLFA contents, and enzyme activities for the understory treatments with a paired-sample $t$ test (SPSS 17.0). Where two subplots within the same plot had the same treatment, we averaged the data before analysis. We investigated the relationships between the soil abiotic properties, PLFA contents, and enzyme activities for the two treatments using redundancy analysis (RDA, CANOCO, version 4.5) and Pearson correlation analysis (SPSS 17.0). We tested the significance of the variables with the Monte Carlo permutation test before applying RDA. Figures were generated using SigmaPlot (version 10.0). A significance level of $P<0.05$ was applied throughout.

\section{Results}

\subsection{Soil abiotic properties}

The results suggest that the soil abiotic properties were influenced by the understory vegetation management (Table 1). The contents of DOC, POC, SOC, $\mathrm{NH}_{4}^{+}-\mathrm{N}$, and $\mathrm{TN}$ were $18 \%, 25 \%, 12 \%, 34 \%$, and $8 \%$ lower in the None treatments than in the Understory treatments $(P<0.05)$, respectively. The SMC and POC/SOC were also $4 \%$ and $15 \%$ lower in the None treatments than in the Understory treatments, respectively $(P<0.05)$. There were no significant differences between the contents of $\mathrm{NO}_{3}^{-}-\mathrm{N}, \mathrm{ST}, \mathrm{pH}$, and the SOC/TN ratios in the None and Understory treatments $(P>0.05)$.

\subsection{Soil PLFAs}

The soil total PLFAs were $27 \%$ lower in the None treatments than in the Understory treatments (Fig. 2). Specifically, the bacterial and fungal PLFAs were $26 \%$ and $20 \%$ lower $(P<0.05)$ in the None treatments than in the Understory treatments, respectively, but there were no significant differences between the $\mathrm{G}^{+}, \mathrm{G}^{-}$, or actinobacterial PLFAs in the two treatments $(P>0.05)$. The fungi/bacteria ratios did not change because the bacterial and fungal PLFAs were both lower in the None treatments.

\subsection{Soil enzyme activities}

The soil enzyme activities varied as the understory vegetation management varied. The potential activities of $\beta \mathrm{G}$, NAG, PPO, and PER were $13 \%, 24 \%, 21 \%$, and $20 \%$ lower in the None treatments than in the Understory treatments (Fig. 3a and b) $(P<0.05)$, respectively, but the potential activities of acid phosphatases did not differ sig- 

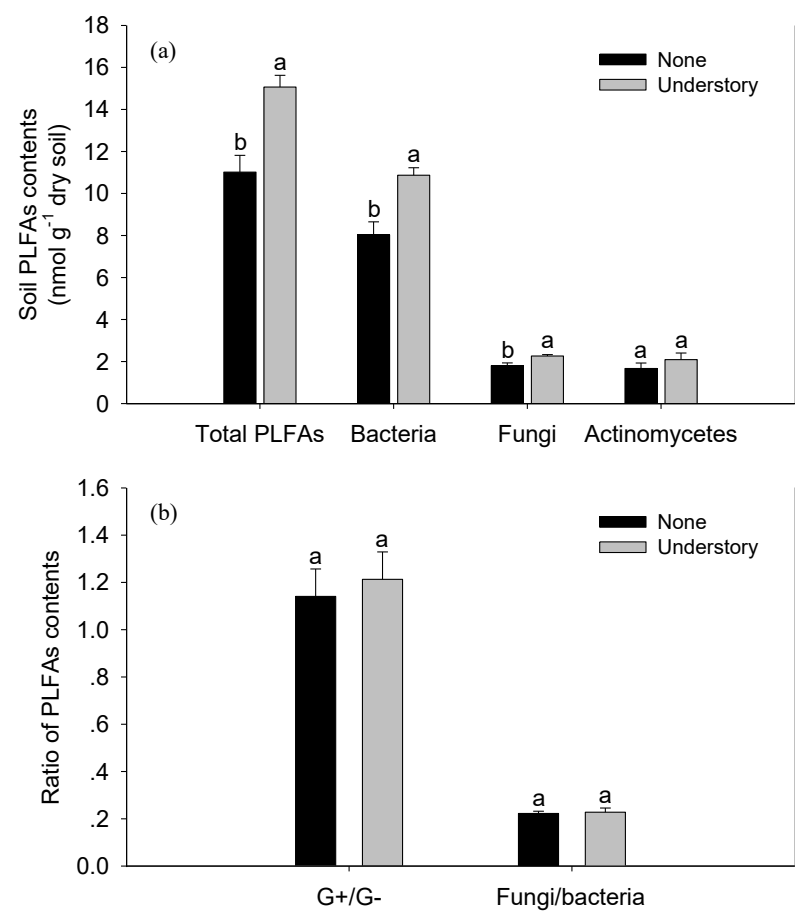

Figure 2. Soil phospholipid fatty acids (PLFAs) in the different understory vegetation treatments. Soil PLFA contents (a); ratio of PLFA contents (b). $\mathrm{G}^{+} / \mathrm{G}^{-}$: ratio of gram positive bacteria to gram negative bacteria; $\mathrm{F} / \mathrm{B}$ : ratio of fungi to bacteria. Different lowercases represent significant differences among the None and Understory treatments $(P<0.05)$. Data are the means \pm standard errors. The same abbreviations apply to Fig. 4.

nificantly $(P>0.05)$ between the two treatments. The ratio of $\ln \mathrm{C}_{\mathrm{enz}} / \ln \mathrm{nAG}$ was $6 \%$ higher in the None treatments than in the Understory treatments, but the ratios of $\ln \mathrm{C}_{\mathrm{enz}} / \ln \mathrm{AP}$ were similar for the different treatments. The trends were enzyme-specific when normalized by the total PLFAs (Fig. 3d and e). The specific activities of the Cacquiring enzymes, i.e., $\alpha \mathrm{G}_{\text {PLFAs }}, \beta \mathrm{G}_{\text {PLFAs }}$ and $\beta \mathrm{X}_{\text {PLFAs }}$, were $40 \%, 22 \%$, and $41 \%$ higher, respectively, in the None treatments than in the Understory treatments $(P<0.05)$, but the specific activities of N- (NAGPLFAs) and P-acquiring enzymes (AP PLFAs) were not significantly different between the two treatments $(P>0.05)$.

\subsection{Correlations between soil enzyme activities, soil PLFAs, and soil abiotic properties}

The first (RD1) and second (RD2) ordination axes explained $62.0 \%$ and $15.5 \%$ of the total variability in the different PLFAs, respectively. Soil temperature, $\mathrm{SMC}, \mathrm{NO}_{3}^{-}-\mathrm{N}$, $\mathrm{NH}_{4}^{+}-\mathrm{N}, \mathrm{DOC}, \mathrm{SOC}$, and SOC/TN were mainly correlated with RD1 (Fig. 4a). Ammonia nitrogen and DOC were positively correlated with bacterial, actinobacterial, and total
PLFAs, and SOC was positively correlated with $\mathrm{G}^{-}$, bacterial, fungal, and total PLFAs $(P<0.05)$ (Table A3).

The first (RD1) and second (RD2) ordination axes explained $50.1 \%$ and $19.9 \%$ of the total variability in the potential enzyme activities, respectively. The contents of DOC, $\mathrm{NO}_{3}^{-}-\mathrm{N}$, and $\mathrm{NH}_{4}^{+}-\mathrm{N}$ were mainly related to RD2 (Fig. 4b). Dissolved organic carbon was positively correlated with $\alpha \mathrm{G}$ and negatively correlated with $\beta \mathrm{X}$ and $\mathrm{AP}$, and $\mathrm{NH}_{4}^{+}-\mathrm{N}$ was positively correlated with $\alpha \mathrm{G}$ and $\beta \mathrm{G}(P<0.05$; Table A3). Bacterial and total PLFAs were positively correlated with $\alpha \mathrm{G}, \beta \mathrm{G}, \mathrm{NAG}, \mathrm{PPO}$, and PER, and fungal PLFAs were positively correlated with $\alpha \mathrm{G}, \beta \mathrm{G}$, and NAG $(P<0.05$; Table A4).

\section{Discussion}

Consistent with our hypothesis, the contents of organic $\mathrm{C}$ (including DOC, POC, and SOC) and $\mathrm{N}$ (including $\mathrm{NH}_{4}^{+}-\mathrm{N}$ and $\mathrm{TN}$ ) were lower in the plots from which the understory vegetation was removed than in those with intact understory vegetation (Table 1), which suggests that understory vegetation promotes $\mathrm{C}$ and $\mathrm{N}$ storage in soil. Other researchers reported minimal changes in the soil physical and chemical properties when the understory vegetation was removed (Xiong et al., 2008; Zhao et al., 2011), and the different results may reflect the variable composition of the understory vegetation (Nilsson and Wardle, 2005). In our study, we removed the litter from all treatments. The roots of the Chinese fir trees may take over the space previously occupied by the understory vegetation and may increase their exudation to compensate for the reduced $\mathrm{C}$ inputs ( $\mathrm{Li}$ et al., 2016), and the residues from the roots of understory vegetation may also decompose in the soil (Li et al., 2013). However, the increased quantities of labile $\mathrm{C}$ from Chinese fir roots and understory vegetation root residues may not fully compensate for the $\mathrm{C}$ loss when the understory vegetation is removed. Additionally, soil C tends to be higher when the plant functional diversity is high (Zhou et al., 2016). When the understory vegetation is removed, the plant diversity decreases, and the soil $\mathrm{C}$ content also decreases. Previously, researchers found that soil $\mathrm{N}$ contents increased when the amount of $\mathrm{N}$ taken up by plants decreased during tree girdling experiments (Kaiser et al., 2010) and in soils without live roots (Loeppmann et al., 2016a). However, we found that the soil $\mathrm{N}$ increased when the understory vegetation remained intact, which suggests that the amount of available $\mathrm{N}$ released from plant roots and SOM degradation exceeded the amount taken up by plants. The POC/SOC ratios were lower for the understory vegetation removal plots than for the plots with intact understory vegetation (Table 1), which suggests that POC declined more strongly than SOC when the understory vegetation was removed. Since POC is related to aggregate stability, the soil in Chinese fir plantations will be more productive when the understory vegetation remains intact (Bouajila and Gallali, 

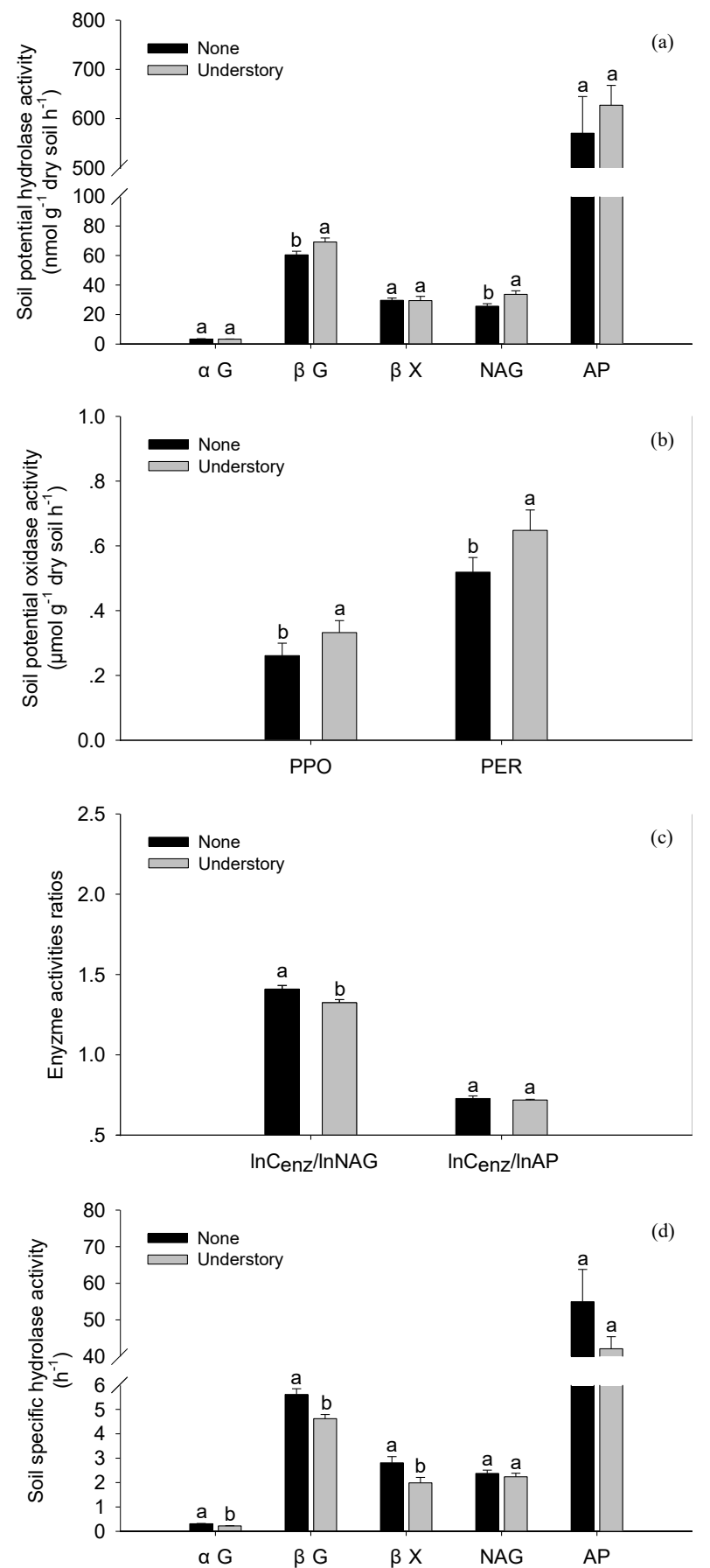

Figure 3. Soil enzyme activities in the different understory vegetation treatments. Soil potential hydrolase activities (a), soil potential oxidase activities (b), enzyme activity ratios (c), and soil hydrolase activities normalized by total PLFAs (d). $\alpha \mathrm{G}: \alpha$-1,4-glucosidase, $\beta \mathrm{G}: \beta$-1,4-glucosidase, NAG: $\beta-1,4-\mathrm{N}$ acetylglucosaminidase, $\beta \mathrm{X}$ : $\beta$-1,4-xylosidase, AP: acid phosphatase, PPO: phenol oxidase, and PER: peroxidase. The same abbreviations apply to Fig. 4.
2010). As also reported by Wang et al. (2014), the SMC decreased when the understory vegetation was removed (Table 1), which shows that the understory vegetation has benefits for soil moisture.

Consistent with our hypothesis, total PLFAs declined when the understory vegetation was removed (Fig. 2). It is known that fungal biomass decreases when understory vegetation was removed (Wu et al., 2011; Liu et al., 2012; Zhao et al., 2013). The PLFAs in AMF were lower in the plots with no understory vegetation (Fig. A1), which reflects the reduced plant diversity. Since certain AMF may only grow when specific plants are present, changes in the plant communities over time will result in changes in their mycorrhizal partners (Hart et al., 2001). Other studies have suggested that decreases in the fungal PLFAs were mainly related to a reduction in mycorrhizal fungi, as mycorrhizal fungi are more dependent on below-ground $\mathrm{C}$ allocation by plants than other fungi (Kaiser et al., 2010). Mycorrhizal species in the understory vegetation included Dicranopteris dichotoma, Vaccinium bracteatum, Loropetalum chinense, and Rhododendron. Chinese fir (arbuscular mycorrhizal plant) monocultures may support fewer fungi biomass than other plantations where the understory vegetation is left intact. The bacterial biomass also decreased after the understory vegetation was removed, mainly because of the decreases in the soil $\mathrm{C}$ and $\mathrm{N}$ (Table A3) and plant diversity (Lamb et al., 2011). Actinobacteria promote the decomposition of recalcitrant $\mathrm{C}$ compounds and, while Brant et al. (2006) considered that they might increase when the available nutrient contents were low, we did not observe such a tendency (Fig. 2), perhaps because of the high variability in the actinobacterial PLFAs in the soils.

Consistent with our hypothesis and the results of Huang et al. (2014), we found that the potential extracellular enzyme activities were lower when there was no understory vegetation (Fig. 3). However, Lin et al. (2012) did not observe any changes in soil enzyme activities when understory vegetation was removed. The soil rhizosphere is a hotspot of microbial activities (Kuzyakov and Blagodatskaya, 2015). Decreases in the quantity and diversity of root exudates in the understory vegetation, and changes in the soil abiotic and biotic properties may cause direct and indirect changes in soil enzyme activities (Liu et al., 2012; Huang et al., 2014). The potential $\mathrm{C}$ hydrolase activity was higher when the understory remained intact, indicating the high soil microbial demand for C. The specific $\mathrm{C}$ hydrolase activities normalized by PLFAs were lower when the understory vegetation remained intact than when it was removed, which may reflect opportunistic microorganisms (microorganisms that use enzyme products rather than produce enzymes) that emerged in response to an increase in the labile $\mathrm{C}$ input (Allison, 2005), and a subsequent decline in the ability of microorganisms to produce $\mathrm{C}$ acquiring enzymes. The ratio of $\mathrm{C}$ - to $\mathrm{N}$-acquiring enzymes increased when the understory vegetation was removed, perhaps because the microbes produced enzymes that acquired 

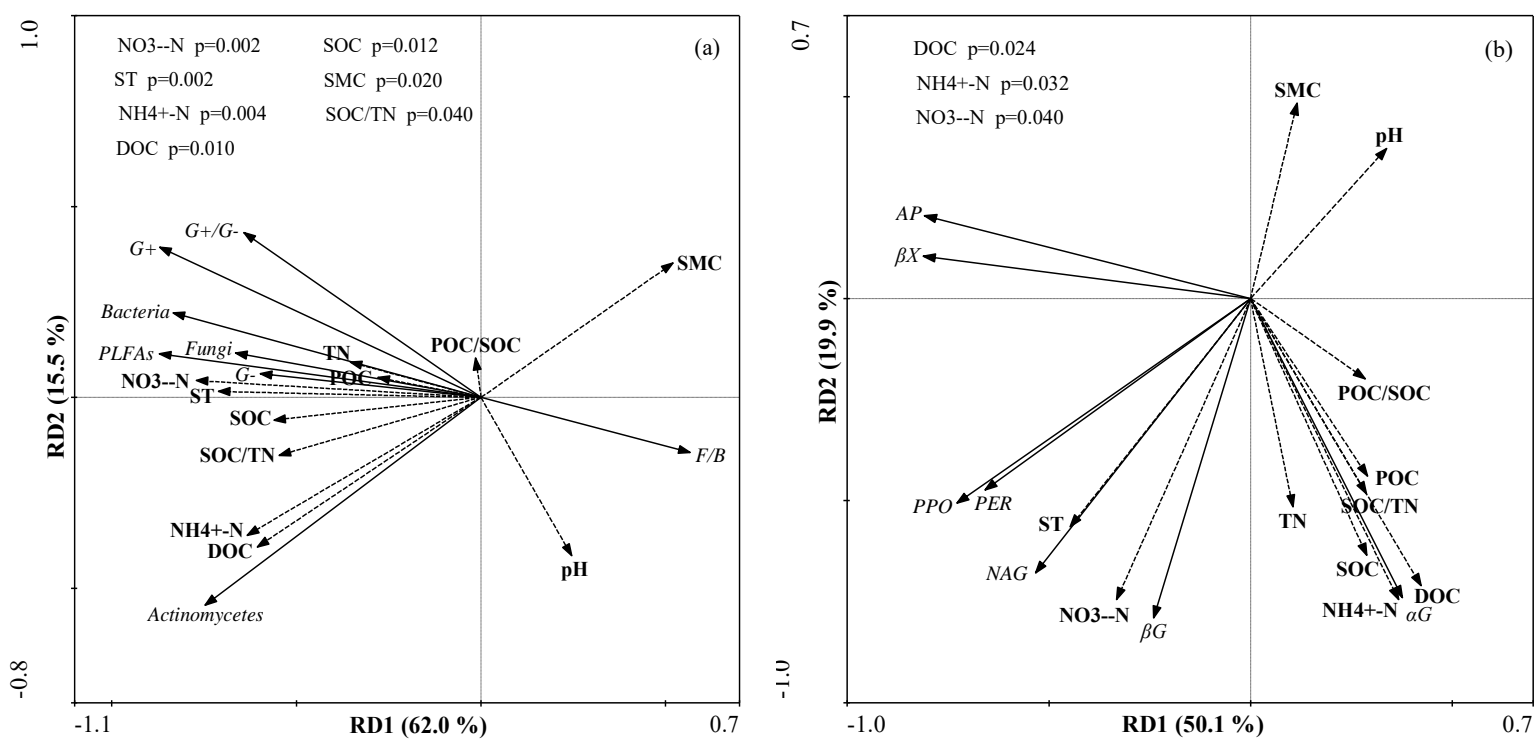

Figure 4. Redundancy analysis of all soil abiotic properties and PLFA contents (a), and potential enzyme activities (b). SMC: soil moisture content, $\mathrm{pH}$ : soil $\mathrm{pH}, \mathrm{NO}_{3}^{-}-\mathrm{N}$ : soil nitrate nitrogen, $\mathrm{NH}_{4}^{+}-\mathrm{N}$ : soil ammonia nitrogen, $\mathrm{TN}$ : soil total nitrogen, DOC: soil dissolved organic carbon, POC: soil particulate organic carbon, SOC: soil organic carbon, POC/SOC: ratio of POC to SOC, and SOC/TN: ratio of SOC to TN.

$\mathrm{C}$ rather than $\mathrm{N}$ when the labile $\mathrm{C}$ inputs were lower. There are various explanations for the changes observed in the potential enzyme activities, as follows: (1) mycorrhizal fungi vanish when understory vegetation is removed (Fekete et al., 2011), which means there are fewer microorganisms to produce enzymes, so the total amount of enzymes decreases. (2) When the understory vegetation remains intact, root exudates are continuously released to soil, but when the understory vegetation is removed, below-ground root residues are the main source of $\mathrm{C}$ for the understory vegetation. Thus, the inputs of $\mathrm{C}$ with different chemical compositions may have influenced the enzyme activities ( $\mathrm{Li}$ et al., 2013).

The activities of $\alpha \mathrm{G}$ and $\beta \mathrm{G}$ were positively correlated with the contents of the soil inorganic $\mathrm{N}$ fractions (Table A3), which suggests that the decomposition of $\mathrm{C}$ decreased because of the reduced availability of $\mathrm{N}$ when the understory vegetation was removed. The size of the soil $\mathrm{C}$ pool reflects the balance between the inputs and outputs of C (De Deyn et al., 2008). When understory vegetation is removed, both the soil C inputs, including root exudates, fine root turnover (Liu et al., 2012), and SOM decomposition rate (Wu et al., 2011; Liu et al., 2012; Zhao et al., 2013), and soil C outputs, such as soil respiration (Wang et al., 2013), decrease. The lower SOC contents in the plots from which the understory vegetation was removed therefore indicate that the removal of understory vegetation had more effect on the outputs of soil $\mathrm{C}$ than on the inputs. Polyphenols are mainly decomposed by PPO, so the decrease in PPO activity may result in an increase in the content of polyphenols that have toxic effects on soil microbes and inhibit hydrolase activities (Sinsabaugh, 2010). Oxidative enzymes are responsible for the degrada- tion of poor-quality, chemically complex compounds, such as lignin, aromatic compounds, and phenolic compounds (Sinsabaugh, 2010). Therefore, the lower activities of PPO and PER observed after the understory vegetation was removed may result in an increase in the content of refractory compounds in SOM.

Phosphorus is generally the most limiting element in the highly weathered red soils in southern China. Soil $\mathrm{P}$ is generally present in an organic form or is immobilized when the contents of $\mathrm{Al}$ and $\mathrm{Fe}$ are high (Margalef et al., 2017). Of all the enzymes we assayed, the activity of AP was the highest (Fig. 3), which may reflect the fact that $P$ was the limiting nutrient in the red soils. Soil microorganisms may produce more phosphatase to mineralize organic $\mathrm{P}$ to meet their demand for P (Allison and Vitousek, 2005). Loeppmann et al. (2016a, b) reported that N-degrading enzymes in the rhizosphere of maize-planted soil increased when the available $\mathrm{N}$ decreased because of plant $\mathrm{N}$ uptake, which suggests that $\mathrm{N}$ demand in the rhizosphere might be regulated by a similar mechanism in the cultivated field; we however did not find any evidence of such a control in our study. The soil nutrient availability affects rhizosphere priming (Dijkstra et al., 2013). The higher potential NAG activity and higher contents of $\mathrm{NH}_{4}^{+}-\mathrm{N}$ in the treatments with the intact understory vegetation suggest that the energy-rich $\mathrm{C}$ compounds released through the roots promoted the production of $\mathrm{N}$-acquiring enzymes that released available $\mathrm{N}$ from SOM. The low potential activity of NAG in the treatments from which the understory vegetation was removed was related to the reduction in the fungal biomass, and reflects the fact that chitin, a major structural component of fungal cell walls (Loeppmann et al., 


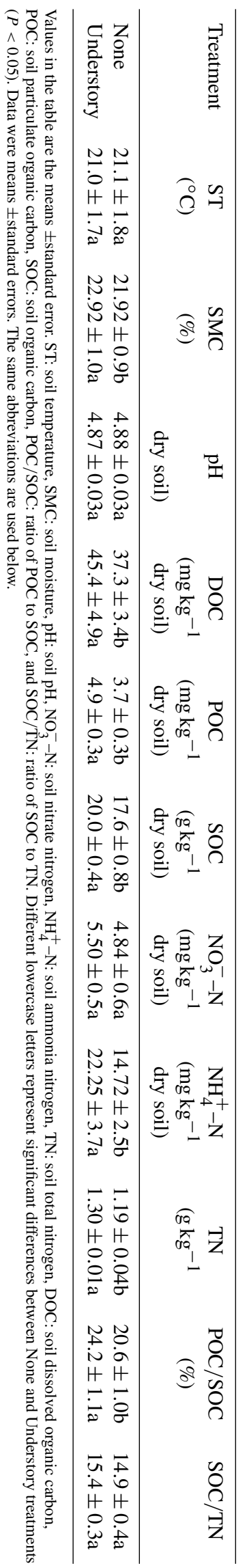

2016b), can be degraded by NAG (Mganga et al., 2015). We did not observe any change in the AP activities when the understory vegetation was removed. Because Chinese firs coexist with fungi and form mycorrhizal associates ( $\mathrm{Li}$ et al., 2011), and mycorrhizal fungi produce soil acid phosphatase (Rosling et al., 2016), these enzymes were most likely produced by Chinese firs. The negative relationships between the potential activity of AP and DOC suggest that DOC was the substrate for microbes, and that large amounts of DOC were consumed when producing P-acquiring enzymes.

\section{Conclusions}

Our results demonstrate that understory vegetation plays an important role in enhancing the soil $\mathrm{C}$ and $\mathrm{N}$ contents and the soil potential activities of $\mathrm{C}$ - and $\mathrm{N}$-hydrolase and oxidase, but does not influence the P-hydrolase activity. The ratio of $\mathrm{C}$ - to $\mathrm{N}$-acquiring enzymes increased after the understory vegetation was removed, which implies that, under lower inputs of labile $\mathrm{C}$, microbes invest more in $\mathrm{C}$-acquiring enzymes than $\mathrm{N}$-acquiring enzymes. The positive relationship between the activities of C-degrading enzymes and the soil inorganic $\mathrm{N}$ contents suggests that $\mathrm{C}$ decomposition was inhibited by the lower available $\mathrm{N}$ contents after understory vegetation was removed. It could be expected that less $\mathrm{N}$ taken up by plants may increase soil $\mathrm{N}$ content after understory vegetation was removed; however, soil $\mathrm{N}$ inputs decrease with reduced understory vegetation root material inputs, which leads to inorganic $\mathrm{N}$ decreases over time. The potential activity of AP was negatively correlated with the content of DOC, which indicates that large amounts of DOC, an energy source, were consumed when producing P-acquiring enzymes. Therefore, understory vegetation can contribute to $\mathrm{C}$ sequestration by enhancing $\mathrm{C}$ inputs to soil, even though $\mathrm{C}$ may be lost from soil with understory vegetation through the degradation of SOM by enzymes. We suggest that, as part of routine forestry management, understory vegetation should not be removed from subtropical Chinese fir plantations.

Data availability. Requests for data or other materials should be directed to Xinyu Zhang (zhangxy@igsnrr.ac.cn). 


\section{Appendix A: Appendix information}

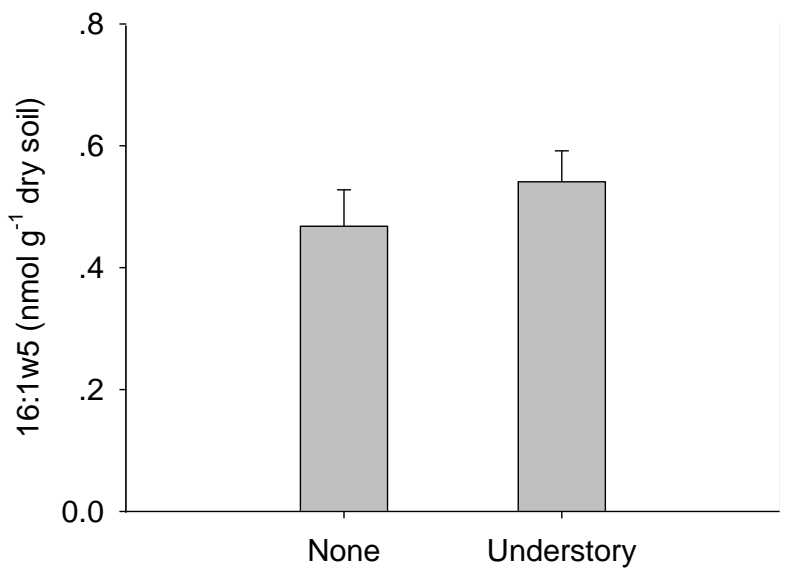

Figure A1. Contents of arbuscular mycorrhizal fungi in the different understory vegetation treatments.

Table A1. Soil enzymes and their corresponding substrates and functions.

\begin{tabular}{|c|c|c|c|c|}
\hline Enzyme & E. C & Abbreviation & Substrate & Function \\
\hline Peroxidase & 1.11.1.7 & PER & L-DOPA & $\begin{array}{l}\text { Oxidizes lignin and aromatic compounds using } \mathrm{H}_{2} \mathrm{O}_{2} \\
\text { or secondary oxidants as an electron acceptor (Sinsabaugh, 2010). }\end{array}$ \\
\hline Phenol oxidase & 1.10.3.2 & PPO & L-DOPA & $\begin{array}{l}\text { Oxidizes phenolic compounds using oxygen as an } \\
\text { electron acceptor (Sinsabaugh, 2010). }\end{array}$ \\
\hline$\alpha$-1,4-glucosidase & 3.2.1.20 & $\alpha \mathrm{G}$ & 4-MUB- $\alpha$-D-glucoside & Releases glucose from starch (Stone et al., 2014). \\
\hline$\beta$-1,4-glucosidase & 3.2 .1 .21 & $\beta \mathrm{G}$ & 4-MUB- $\beta$-D-glucoside & Releases glucose from cellulose (Stone et al., 2014). \\
\hline$\beta$-1,4-xylosidase & 3.2.1.37 & $\beta \mathrm{X}$ & 4-MUB- $\beta$-D-xyloside & Releases xylose from hemicellulose (Stone et al., 2014). \\
\hline $\begin{array}{l}\beta-1,4-\mathrm{N}- \\
\text { acetylglucosaminidase }\end{array}$ & 3.2.1.14 & NAG & $\begin{array}{l}\text { 4-MUB-N-acetyl- } \beta \text {-D- } \\
\text { glucosaminide }\end{array}$ & $\begin{array}{l}\text { Releases N-acetyl glucosamine from oligosaccharides } \\
\text { (Stone et al., 2014). }\end{array}$ \\
\hline Acid phosphatase & 3.1.3.1 & AP & 4-MUB-phosphate & Releases phosphate groups (Stone et al., 2014). \\
\hline
\end{tabular}


Table A2. Enzyme indexes: the potential enzyme activity and the total PLFA contents were used to calculate different enzyme indexes. $\alpha$-1,4-glucosidase $(\alpha \mathrm{G}), \beta$-1,4-glucosidase $(\beta \mathrm{G})$, and $\beta$-1,4-xylosidase $(\beta \mathrm{X})$ represented $\mathrm{C}$-acquiring enzymes, whereas $\beta$-1,4-Nacetylglucosaminidase(NAG) represented $\mathrm{N}$-cycling enzymes. Acid phosphatase (AP) represented P-acquiring enzymes.

\begin{tabular}{|c|c|c|}
\hline Enzyme indexes & Description & Reference \\
\hline$\alpha \mathrm{G}_{\text {PLFAs }} ; \beta \mathrm{G}_{\text {PLFAs }} ; \beta \mathrm{X}_{\text {PLFAs }}$ & $\begin{array}{l}\text { Specific enzyme activity of C-acquiring enzymes } \\
\text { (enzyme activities to total PLFAs) }\end{array}$ & Zhang et al. $(2015,2017)$ \\
\hline $\mathrm{NAG}_{\text {PLFAs }}$ & $\begin{array}{l}\text { Specific enzyme activity of N-acquiring enzymes } \\
\text { (enzyme activities to total PLFAs) }\end{array}$ & Zhang et al. $(2015,2017)$ \\
\hline $\mathrm{AP}_{\text {PLFAs }}$ & $\begin{array}{l}\text { Specific enzyme activity of P-acquiring enzymes } \\
\text { (enzyme activities to total PLFAs) }\end{array}$ & Zhang et al. $(2015,2017)$ \\
\hline $\ln \mathrm{C}_{\mathrm{enz}} / \ln \mathrm{NAG}$ & Ratio of $\mathrm{C}$ - to $\mathrm{N}$-acquiring enzymes & $\begin{array}{l}\text { Stone et al. (2014), Loeppmann et al. } \\
\text { (2016a), Xu et al. (2017) }\end{array}$ \\
\hline $\ln \mathrm{C}_{\mathrm{enz}} / \ln \mathrm{AP}$ & Ratio of C- to P-acquiring enzymes & $\begin{array}{l}\text { Stone et al. (2014), Loeppmann et al. } \\
\text { (2016a), Xu et al. (2017) }\end{array}$ \\
\hline
\end{tabular}

$\mathrm{C}_{\mathrm{enz}}$ : the total $\mathrm{C}$-acquiring enzyme activity (the potential activities of $\alpha \mathrm{G}+\beta \mathrm{G}+\beta \mathrm{X}$ ).

Table A3. Pearson correlation coefficients between soil abiotic properties, PLFA contents, and potential enzyme activities.

\begin{tabular}{|c|c|c|c|c|c|c|c|c|c|c|c|c|}
\hline $\begin{array}{l}\text { Abiotic } \\
\text { properties }\end{array}$ & & ST & SMC & $\mathrm{pH}$ & $\mathrm{NO}_{3}^{-}-\mathrm{N}$ & $\mathrm{NH}_{4}^{+}-\mathrm{N}$ & $\mathrm{TN}$ & DOC & POC & SOC & $\mathrm{POC} / \mathrm{SOC}$ & $\mathrm{SOC} / \mathrm{TN}$ \\
\hline \multirow[t]{8}{*}{ PLFAs } & $\mathrm{G}^{+}$ & $0.77^{* *}$ & -0.45 & -0.38 & $0.72^{* *}$ & 0.28 & 0.11 & 0.24 & 0.06 & 0.26 & -0.13 & 0.39 \\
\hline & $\mathrm{G}^{-}$ & -0.05 & 0.15 & -0.01 & 0.18 & 0.38 & $0.70^{* *}$ & 0.27 & $0.52^{*}$ & $0.68^{* *}$ & 0.33 & 0.29 \\
\hline & Bacteria & 0.44 & -0.24 & -0.25 & $0.58^{*}$ & $0.62^{* *}$ & $0.53^{*}$ & $0.57^{*}$ & $0.48^{*}$ & $0.65^{* *}$ & 0.27 & 0.46 \\
\hline & Fungi & 0.11 & -0.02 & -0.20 & 0.40 & 0.43 & $0.68^{* *}$ & 0.39 & $0.56^{*}$ & $0.72^{* *}$ & 0.38 & 0.36 \\
\hline & Actinobacteria & $0.65^{* *}$ & $-0.67^{* *}$ & -0.13 & $0.69^{* *}$ & $0.69^{* *}$ & 0.22 & $0.63^{* *}$ & 0.08 & 0.36 & -0.14 & 0.37 \\
\hline & PLFAs & $0.54^{*}$ & -0.37 & -0.26 & $0.69^{* *}$ & $0.63^{* *}$ & $0.47^{*}$ & $0.60^{* *}$ & 0.41 & $0.58^{*}$ & 0.20 & 0.43 \\
\hline & $\mathrm{G}^{+} / \mathrm{G}^{-}$ & $0.88^{* *}$ & $-0.57^{*}$ & -0.40 & $0.71^{* *}$ & 0.14 & -0.17 & 0.18 & -0.17 & -0.02 & -0.29 & 0.25 \\
\hline & $\mathrm{F} / \mathrm{B}$ & $-0.50^{*}$ & 0.22 & -0.01 & -0.30 & -0.17 & -0.07 & -0.15 & 0.03 & -0.18 & 0.22 & -0.24 \\
\hline \multirow[t]{7}{*}{ Enzymes } & $\alpha \mathrm{G}$ & 0.40 & $-0.54^{*}$ & -0.30 & $0.51^{*}$ & $0.64^{* *}$ & 0.30 & $0.69^{* *}$ & 0.23 & 0.45 & 0.04 & 0.44 \\
\hline & $\beta \mathrm{G}$ & $0.57^{*}$ & -0.41 & -0.40 & $0.67^{* *}$ & $0.50^{*}$ & 0.38 & 0.42 & 0.16 & 0.37 & -0.03 & 0.22 \\
\hline & NAG & $0.54^{*}$ & -0.30 & -0.40 & $0.64^{* *}$ & 0.32 & 0.36 & 0.23 & 0.25 & 0.32 & 0.11 & 0.15 \\
\hline & $\beta \mathrm{X}$ & 0.30 & -0.06 & $-0.49^{*}$ & 0.30 & -0.46 & -0.06 & $-0.52^{*}$ & -0.38 & -0.34 & -0.38 & -0.43 \\
\hline & $\mathrm{AP}$ & 0.28 & 0.00 & -0.16 & 0.09 & -0.44 & -0.21 & $-0.48^{*}$ & -0.36 & -0.38 & -0.32 & -0.33 \\
\hline & PPO & $0.86^{* *}$ & $-0.57^{*}$ & -0.33 & $0.72^{* *}$ & 0.25 & -0.01 & 0.23 & -0.13 & 0.05 & -0.28 & 0.14 \\
\hline & PER & $0.81^{* *}$ & $-0.54^{*}$ & -0.12 & $0.61^{* *}$ & 0.37 & -0.01 & 0.32 & -0.03 & 0.13 & -0.18 & 0.23 \\
\hline
\end{tabular}

Values are Pearson $r$ value. ${ }^{*}$ indicates a significant difference at $P<0.05$; ${ }^{* *}$ indicates a significant difference at $P<0.01$. $\mathrm{G}^{+}$: gram positive bacteria, $\mathrm{G}^{-}$: gram negative bacteria, PLFAs: total PLFAs, $\mathrm{G}^{+} / \mathrm{G}^{-}$: ratio of $\mathrm{G}^{+}$and $\mathrm{G}^{-}, \mathrm{F} / \mathrm{B}$ : ratio of fungi to bacteria. $\alpha \mathrm{G}: \alpha$-1,4-glucosidase, $\beta \mathrm{G}: \beta$-1,4-glucosidase, NGA: $\beta$-1,4-N-acetylglucosaminidase, $\beta \mathrm{X}$ : $\beta$-1,4-xylosidase, AP: acid phosphatase, PPO: phenol oxidase, PER: peroxidase. These abbreviations apply to Tables A4-A7.

Table A4. Pearson correlation coefficients between PLFA contents and potential enzyme activities.

\begin{tabular}{lrrrrrrrr}
\hline Factors & $\mathrm{G}^{+}$ & $\mathrm{G}^{-}$ & Bacteria & Fungi & Actinobacteria & PLFAs & $\mathrm{G}^{+} / \mathrm{G}^{-}$ & $\mathrm{F} / \mathrm{B}$ \\
\hline$\alpha \mathrm{G}$ & 0.29 & 0.46 & $0.53^{*}$ & $0.51^{*}$ & $0.61^{* *}$ & $0.48^{*}$ & 0.12 & -0.17 \\
$\beta \mathrm{G}$ & $0.67^{* *}$ & $0.57^{*}$ & $0.83^{* *}$ & $0.65^{* *}$ & $0.70^{* *}$ & $0.83^{* *}$ & $0.52^{*}$ & -0.27 \\
$\beta \mathrm{X}$ & $0.71^{* *}$ & 0.46 & $0.73^{* *}$ & $0.58^{*}$ & 0.47 & $0.73^{* *}$ & $0.60^{* *}$ & -0.28 \\
$\mathrm{NAG}$ & 0.40 & -0.15 & 0.01 & 0.02 & -0.11 & 0.02 & $0.52^{*}$ & -0.02 \\
$\mathrm{AP}$ & 0.32 & -0.24 & 0.03 & -0.14 & -0.15 & 0.08 & $0.49^{*}$ & -0.07 \\
PPO & $0.84^{* *}$ & 0.09 & $0.57^{*}$ & 0.28 & 0.46 & $0.64^{* *}$ & $0.91^{* *}$ & -0.44 \\
PER & $0.79^{* *}$ & 0.04 & $0.55^{*}$ & 0.21 & $0.47^{*}$ & $0.62^{* *}$ & $0.86^{* *}$ & -0.46 \\
\hline
\end{tabular}




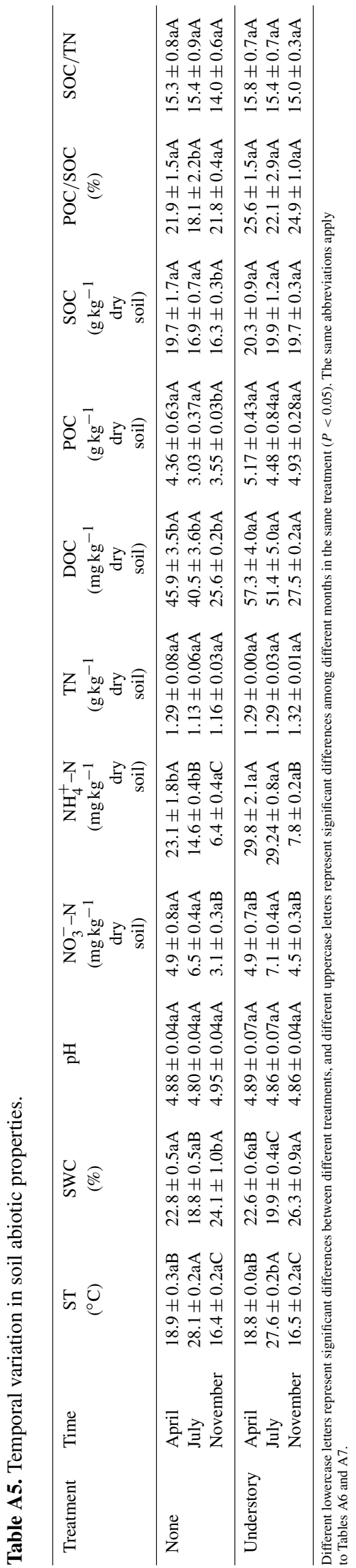

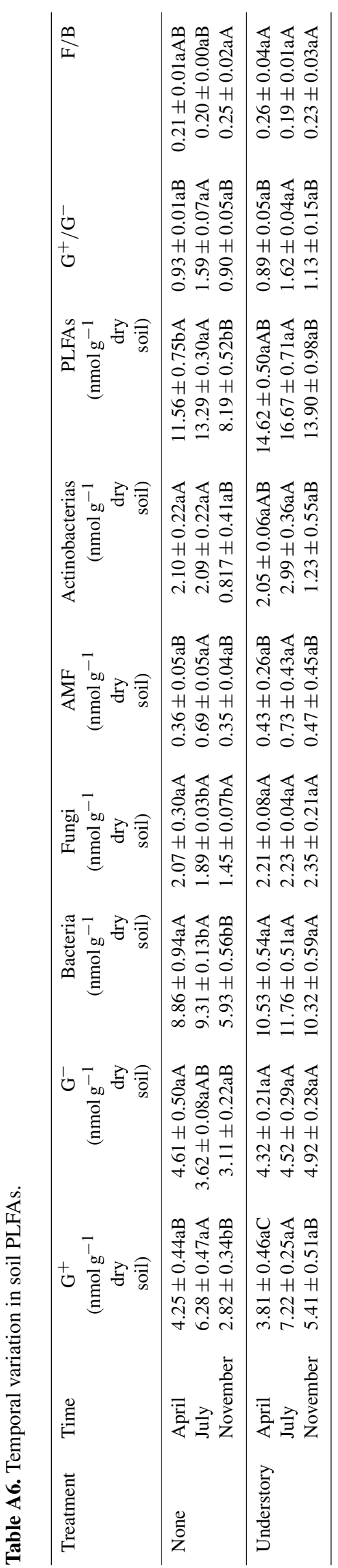

Biogeosciences, 15, 4481-4494, 2018 
Table A7. Temporal variation in soil potential enzyme activities.

\begin{tabular}{|c|c|c|c|c|c|c|c|c|}
\hline Treatment & Time & $\begin{array}{r}\alpha \mathrm{G} \\
\left(\mathrm{nmol} \mathrm{g}^{-1} \text { dry }\right. \\
\left.\operatorname{soil~h}^{-1}\right)\end{array}$ & $\begin{array}{r}\beta \mathrm{G} \\
\left(\mathrm{nmol} \mathrm{g}^{-1} \text { dry }\right. \\
\left.\text { soil h}^{-1}\right)\end{array}$ & $\begin{array}{r}\beta \mathrm{X} \\
\left(\mathrm{nmol} \mathrm{g}^{-1} \text { dry }\right. \\
\left.\text { soil h }^{-1}\right)\end{array}$ & $\begin{array}{c}\text { NAG } \\
\left(\mathrm{nmol} \mathrm{g}^{-1} \text { dry }\right. \\
\left.\text { soil h }^{-1}\right)\end{array}$ & $\begin{array}{r}\text { AP } \\
\left(\mathrm{nmol} \mathrm{g}^{-1} \text { dry }\right. \\
\left.\text { soil h}^{-1}\right)\end{array}$ & $\begin{array}{c}\text { PPO } \\
\left(\mathrm{nmol} \mathrm{g}^{-1} \mathrm{dry}\right. \\
\left.\text { soil h}^{-1}\right)\end{array}$ & $\begin{array}{c}\text { PER } \\
\left(\mathrm{nmol} \mathrm{g}^{-1} \text { dry }\right. \\
\left.\text { soil h }^{-1}\right)\end{array}$ \\
\hline \multirow[t]{3}{*}{ None } & & $3.93 \pm 0.41 \mathrm{aA}$ & $61.9 \pm 4.3 \mathrm{aAB}$ & $24.8 \pm 0.2 \mathrm{aB}$ & $24.9 \pm 3.2 \mathrm{aA}$ & $300.5 \pm 22.9 \mathrm{aB}$ & $0.18 \pm 0.02 \mathrm{aB}$ & $0.40 \pm 0.03 \mathrm{bB}$ \\
\hline & $\mathrm{Ju}$ & $0.09 \mathrm{aA}$ & $1.3 \mathrm{aA}$ & $5 \pm 2.7 \mathrm{aA}$ & & $9.8 \mathrm{aA}$ & & $03 \mathrm{bA}$ \\
\hline & November & $2.48 \pm 0.12 \mathrm{aB}$ & $52.8 \pm 2.1 \mathrm{aB}$ & $30.5 \pm 1.7 \mathrm{aAB}$ & $22.8 \pm 2.0 \mathrm{bA}$ & $698.63 \pm 70.3 \mathrm{aA}$ & $0.20 \pm($ & $0.47 \pm 0$ \\
\hline \multirow[t]{3}{*}{ Understory } & & $3.72 \pm 0.15 \mathrm{aA}$ & $65.9 \pm 3.9 \mathrm{aA}$ & $213+58 \mathrm{~A}$ & $26.8 \pm 3.1 \mathrm{aB}$ & $492.4 \pm 48.8 \mathrm{aB}$ & $0.24 \pm$ & $0.52 \pm 0.03 \mathrm{aB}$ \\
\hline & July & $25+010$ & $8+610$ & $2+10$ & & & & $.04 \mathrm{aA}$ \\
\hline & November & $2.90 \pm 0.12 \mathrm{aB}$ & $65.7 \pm 2.3 \mathrm{aA}$ & $33.8 \pm 2.8 \mathrm{aA}$ & $32.6 \pm 1.6 \mathrm{aB}$ & $689.32 \pm 35.1 \mathrm{aA}$ & $0.28 \pm 0.01 \mathrm{aB}$ & $0.53 \pm 0.04 \mathrm{aB}$ \\
\hline
\end{tabular}


Author contributions. XYZ, HMW, XLF, FSC, XMS, XFW designed the study; YY, CZ, and SZW performed the study and analyzed data; YY, XYZ, and JFW wrote the paper.

Competing interests. The authors declare that they have no conflict of interest.

Acknowledgements. This work was jointly financed by the National Natural Science Foundation of China (nos. 41571251 and 41571130043).

Edited by: Anja Rammig

Reviewed by: three anonymous referees

\section{References}

Allison, S. D.: Cheaters, diffusion and nutrients constrain decomposition by microbial enzymes in spatially structured environments, Ecol. Lett., 8, 626-635, 2005.

Allison, S. D. and Vitousek, P. M.: Responses of extracellular enzymes to simple and complex nutrient inputs, Soil Biol. Biochem., 37, 937-944, 2005.

Bao, S. D.: Soil and Agricultural Chemistry Analysis, 3rd Edn., Agricultrue Press, Beijing, 2008.

Bossio, D. A. and Scow, K. M.: Impacts of carbon and flooding on soil microbial communities: Phospholipid fatty acid profiles and substrate utilization patterns, Microb. Ecol., 35, 265-278, 1998.

Bouajila, A. and Gallali, T.: Land use effect on soil and particulate organic carbon, and aggregate stability in some soils in Tunisia, Afr. J. Agric. Res., 5, 764-774, 2010.

Bradley, K., Hancock, J. E., Giardina, C. P., and Pregitzer, K. S.: Soil microbial community responses to altered lignin biosynthesis in Populus tremuloides vary among three distinct soils, Plant Soil, 294, 185-201, 2007.

Brant, J. B., Myrold, D. D., and Sulzman, E. W.: Root controls on soil microbial community structure in forest soils, Oecologia, 148, 650-659, 2006.

Burns, R. G., DeForest, J. L., Marxsen, J., Sinsabaugh, R. L., Stromberger, M. E., Wallenstein, M. D., Weintraub, M. N., and Zoppini, A.: Soil enzymes in a changing environment: current knowledge and future directions, Soil Biol. Biochem., 58, 216234, 2013.

De Deyn, G. B., Cornelissen, J. H. C., and Bardgett, R. D.: Plant functional traits and soil carbon sequestration in contrasting biomes, Ecol. Lett., 11, 516-531, 2008.

DeForest, J. L.: The influence of time, storage temperature, and substrate age on potential soil enzyme activity in acidic forest soils using MUB-linked substrates and L-DOPA, Soil Biol. Biochem., 41, 1180-1186, 2009.

Denef, K., Roobroeck, D., Wadu, M. C. W. M., Lootens, P., and Boeckx, P.: Microbial community composition and rhizodepositcarbon assimilation in differently managed temperate grassland soils, Soil Biol. Biochem., 44, 144-153, 2009.

Dijkstra, F. A., Carrillo, Y., Pendall, E., and Morgan, J. A.: Rhizosphere priming: a nutrient, Front. Microbiol., 4, 1-8, 2013.
Fekete, I., Varga, C., Kotroczó, Z., Tóth, J. A., and Várbíró, G.: The relation between various detritus inputs and soil enzyme activities in a Central European deciduous forest, Geoderma, 167, 15-21, 2011.

Fu, X. L., Yang, F. T., Wang, J. L., Di, Y. B., Dai, X. Q., Zhang, X. Y., and Wang, H. M.: Understory vegetation leads to changes in soil acidity and in microbial communities 27 years after reforestation, Sci. Total Environ., 502, 280-286, 2015.

Garten, C. T., Post, W. M., Hanson, P. J., and Cooper, L. W.: Forest soil carbon inventories and dynamics along an elevation gradient in the southern Appalachian Mountains, Biogeochemistry, 42, 115-145, 1999.

Hart, M. M., Reader, R. J., and Klironomos, J. N.: Life-history strategies of arbuscular mycorrhizal fungi in relation to their successional dynamics, Mycologia, 93, 1186-1194, 2001.

Huang, Y. M., Yang, W. Q., Zhang, J., Lu, C. T., Liu, X., Wang, W., Guo, W., and Zhang, D. J.: Response of soil microorganism and soil enzyme activity to understory plant removal in the subalpine coniferous plantation of western Sichuan, Acta Ecol. Sin., 34, 4183-4192, 2014.

Huang, Z. Q., He, Z. M., Wan, X. H., Hu, Z. H., Fan, S. H., and Yang, Y. S.: Harvest residue management effects on tree growth and ecosystem carbon in a Chinese fir plantation in subtropical China, Plant Soil, 364, 303-314, 2013.

Jones, D. L. and Willett, V. B.: Experimental evaluation of methods to quantify dissolved organic nitrogen (DON) and dissolved organic carbon (DOC) in soil, Soil Biol. Biochem., 38, 991-999, 2006.

Kaiser, C., Koranda, M., Kitzler, B., Fuchslueger, L., Schnecker, J., Schweiger, P., Rasche, F., Zechmeister-Boltenstern, S., Sessitsch, A., and Richter, A.: Belowground carbon allocation by trees drives seasonal patterns of extracellular enzyme activities by altering microbial community composition in a beech forest soil, New Phytol., 187, 843-858, 2010.

Kuzyakov, Y. and Blagodatskaya, E.: Microbial hotspots and hot moments in soil: Concept \& review, Soil Biol. Biochem., 83, 184-199, 2015.

Lamb, E. G., Kennedy, N., and Siciliano, S. D.: Effects of plant species richness and evenness on soil microbial community diversity and function, Plant Soil, 338, 483-495, 2011.

Li, L., Zhou, G. Y., Liu, J. A., and Li, H.: The resource investigation and community structure characteristics of mycorrhizal fungi associated with Chinese fir, Afr. J. Biotechnol., 10, 57195724, 2011.

Li, M. H., Du, Z., Pan, H. L., Yan, C. F., Xiao, W. F., and Lei, J. P.: Effects of neighboring woody plants on target trees with emphasis on effects of understory shrubs on overstory physiology in forest communities: a mini-review, Commun. Ecol., 13, 117$128,2016$.

Li, Y. F., Zhang, J. J., Chang, S. X., Jiang, P. K., Zhou, G. M., Fu, S. L., Yan, E. R., Wu, J. S., and Lin, L.: Long-term intensive management effects on soil organic carbon pools and chemical composition in Moso bamboo (Phyllostachys pubescens) forests in subtropical China, Forest Ecol. Manage., 303, 121-130, 2013.

Lin, G., Zhao, Q., Zhao, L., Li, H. C., and Zeng, D. H.: Effects of understory removal and nitrogen addition on the soil chemical and biological properties of Pinus sylvestris var. mongolica plantation in Keerqin Sandy Land, Chin. J. Appl. Ecol., 23, 11881194, 2012. 
Liu, Z. F., Wu, J. P., Zhou, L. X., Lin, Y. B., and Fu, S. L.: Effect of understory fern (Dicranopteris dichotoma) removal on substrate utilization patterns of culturable soil bacterial communities in subtropical Eucalyptus plantations, Pedobiologia, 55, 713, 2012.

Loeppmann, S., Biagodatskaya, E., Pausch, J., and Kuzyakov, Y.: Enzyme properties down the soil profile - A matter of substrate quality in rhizosphere and detritusphere, Soil Biol. Biochem., 103, 274-283, 2016a.

Loeppmann, S., Semenov, M., Blagodatskaya, E., and Kuzyakov, Y.: Substrate quality affects microbial- and enzyme activities in rooted soil, J. Plant Nutr. Soil Sci., 179, 39-47, 2016 b.

Margalef, O., Sardans, J., Fernandez-Martinez, M., MolownyHoras, R., Janssens, I. A., Ciais, P., Goll, D., Richter, A., Obersteiner, M., Asensio, D., and Penuelas, J.: Global patterns of phosphatase activity in natural soils, Sci. Rep., 7, 1337, https://doi.org/10.1038/s41598-017-01418-8, 2017.

McNear Jr., D. H.: The rhizosphere roots soil and everything in between, Nat. Educ. Know., 4, 1, 2013.

Mganga, K. Z., Razavi, B. S., and Kuzyakov, Y.: Microbial and enzymes response to nutrient additions in soils of Mt. Kilimanjaro region depending on land use, Eur. J. Soil Biol., 69, 33-40, 2015.

Murugan, R., Beggi, F., and Kumar, S.: Belowground carbon allocation by trees, understory vegetation and soil type alter microbial community composition and nutrient cycling in tropical Eucalyptus plantation, Soil Biol. Biochem., 76, 257-267, 2014.

Nannipieri, P., Trasar-Cepeda, C., and Dick, R. P.: Soil enzyme activity: a brief history and biochemistry as a basis for appropriate interpretations and meta-analysis, Biol. Fertil. Soils, 54, 11-19, 2018.

Nilsson, M. C. and Wardle, D. A.: Understory vegetation as a forest ecosystem driver: evidence from the northern Swedish boreal forest, Front. Ecol. Environ., 3, 421-428, 2005.

Rosling, A., Midgley, M. G., Cheeke, T., Urbina, H., Fransson, P., and Phillips, R. P.: Phosphorus cycling in deciduous forest soil differs between stands dominated by ecto- and arbuscular mycorrhizal trees, New Phytol., 209, 1184-1195, 2016.

Saiya-Cork, K. R., Sinsabaugh, R. L., and Zak, D. R.: The effects of long term nitrogen deposition on extracellular enzyme activity in an Acer saccharum forest soil, Soil Biol. Biochem., 34, 13091315, 2002.

Sinsabaugh, R. L.: Phenol oxidase, peroxidase and organic matter dynamics of soil, Soil Biol. Biochem., 24, 391-401, 2010.

Soil Survey Staff: Soil taxonomy: a basic system of soil classification for making and interpreting soil surveys, 2nd Edn., Government Printing Office, Washington, D.C., 1999.

Stone, M. M., DeForest, J. L., and Plante, A. F.: Changes in extracellular enzyme activity and microbial community structure with soil depth at the Luquillo Critical Zone Observatory, Soil Biol. Biochem., 75, 240-241, 2014.

Trasar-Cepeda, C., Leiros, M. C., and Gil-Sotres, F.: Hydrolytic enzyme activities in agricultural and forest soils. Some implications for their use as indicators of soil quality, Soil Biol. Biochem., 40, 2146-2155, 2008.

Urcelay, C., Diaz, S., Gurvich, D. E., Chapin, F. S., Cuevas, E., and Dominguez, L. S.: Mycorrhizal community resilience in response to experimental plant functional type removals in a woody ecosystem, J. Ecol., 97, 1291-1301, 2009.
Wang, F. M., Zou, B., Li, H. F., and Li, Z. A.: The effect of understory removal on microclimate and soil properties in two subtropical lumber plantations, J. Forest Res., 19, 238-243, 2014.

Wang, Q. K., He, T. X., Wang, S. L., and Liu, L.: Carbon input manipulation affects soil respiration and microbial community composition in a subtropical coniferous forest, Agr. Forest. Meteorol., 178, 152-160, 2013.

Wang, X. L., Zhao, J., Wu, J. P., Chen, H., Lin, Y. B., Zhou, L. $\mathrm{X}$., and Fu, S. L.: Impacts of understory species removal and/or addition on soil respiration in a mixed forest plantation with native species in southern China, Forest Ecol. Manage., 261, 10531060, 2011.

Wu, J. P., Liu, Z. F., Wang, X. L., Sun, Y. X., Zhou, L. X., Lin, Y. B., and $\mathrm{Fu}, \mathrm{S}$. L.: Effects of understory removal and tree girdling on soil microbial community composition and litter decomposition in two Eucalyptus plantations in South China, Funct. Ecol., 25, 921-931, 2011.

Xiong, Y. M., Xia, H. P., Li, Z. A., Cai, X. A., and Fu, S. L.: Impacts of litter and understory removal on soil properties in a subtropical Acacia mangium plantation in China, Plant Soil, 304, 179-188, 2008.

Xu, Z. W., Yu, G. R., Zhang, X. Y., He, N. P., Wang, Q. F., Wang, S. Z., Wang, R. L., Zhao, N., Jia, Y. L., and Wang, C. Y.: Soil enzyme activity and stoichiometry in forest ecosystems along the North-South Transect in eastern China (NSTEC), Soil Biol. Biochem., 104, 152-163, 2017.

Yu, G. R., Chen, Z., Piao, S. L., Peng, C. H., Ciais, P., Wang, Q. F., Li, X. R., and Zhu, X. J.: High carbon dioxide uptake by subtropical forest ecosystems in the East Asian monsoon region, P. Natl. Acad. Sci. USA, 111, 4910-4915, 2014.

Zhang, C., Zhang, X.-Y., Zou, H.-T., Kou, L., Yang, Y., Wen, X.F., Li, S.-G., Wang, H.-M., and Sun, X.-M.: Contrasting effects of ammonium and nitrate additions on the biomass of soil microbial communities and enzyme activities in subtropical China, Biogeosciences, 14, 4815-4827, https://doi.org/10.5194/bg-144815-2017, 2017.

Zhang, J. J., Li, Y. F., Chang, S. X., Jiang, P. K., Zhou, G. M., Liu, J., Wu, J. S., and Shen, Z. M.: Understory vegetation management affected greenhouse gas emissions and labile organic carbon pools in an intensively managed Chinese chestnut plantation, Plant Soil, 376, 363-375, 2014.

Zhang, X. Y., Dong, W. Y., Dai, X. Q., Schaeffer, S., Yang, F. T., Radosevich, M., Xu, L. L., and Sun, X. M.: Responses of absolute and specific soil enzyme activities to long term additions of organic and mineral fertilizer, Sci. Total Environ., 536, 59-67, 2015.

Zhao, J., Wang, X. L., Shao, Y. H., Xu, G. L., and Fu, S. L.: Effects of vegetation removal on soil properties and decomposer organisms, Soil Biol. Biochem., 45, 954-960, 2011.

Zhao, J., Wan, S. Z., Fu, S. L., Wang, X. L., Wang, M., Liang, C. F., Chen, Y. Q., and Zhu, X. L.: Effects of understory removal and nitrogen fertilization on soil microbial communities in Eucalyptus plantations, Forest Ecol. Manage., 310, 80-86, 2013.

Zhou, L. L., Cai, L. P., He, Z. M., Wang, R. W., Wu, P. F., and Ma, X. Q.: Thinning increases understory diversity and biomass, and improves soil properties without decreasing growth of Chinese fir in southern China, Environ. Sci. Pollut. Res., 23, 24135-24150, 2016. 